\title{
20th century mass balance and thermal regime change at Scott Turnerbreen, Svalbard
}

\author{
Righard Hodgkins, ${ }^{1}$ Jon Ove Hagen, ${ }^{2}$ Svein-Erik Hamran ${ }^{3}$ \\ ${ }^{1}$ Department of Geography, Royal Holloway, University of London, Egham, Surrey TW20 0EX, England \\ ${ }^{2}$ Department of Physical Geography, University of Oslo, P.O. Box 1042 Blindern, N-0316 Oslo, Norway \\ ${ }^{3}$ Division for Electronics, Norwegian Defence Research Establishment, P.O. Box 25, N-2007 Kjeller, Norway
}

\begin{abstract}
The changing geometry and thermal structure of Scott Turnerbreen, a $3.3 \mathrm{~km}^{2}$ glacier located at $78^{\circ} \mathrm{N}$ in the Svalbard archipelago, is documented. A net mass balance of $-0.58 \mathrm{~m} \mathrm{a}^{-1}$ w.e. is determined for the period 1936-93, by comparing a recent topographic survey with earlier maps. The thermal regime was investigated with multifrequency radar and borehole thermistors. Basal temperatures of $-4.1^{\circ}$ and $-3.3^{\circ} \mathrm{C}$ were measured, and observed temperature gradients indicate that the entire bed is frozen. This interpretation is confirmed by continuous radar profiling, which demonstrates the absence of high-frequency scattering from temperate ice. However, with the reconstructed 1936 icethickness distribution, at least $2 \mathrm{~km}$ of the length of the glacier bed would be at the pressure-melting temperature. The 20th century mass-balance history of Scott Turnerbreen is likely to have been influenced by a surge occurring around 1930, which meant that the glacier was already in a state of disequilibrium before the abrupt climate perturbation marking the termination of the Little Ice Age. A significant loss of mass has been accompanied by a transition from inferred polythermal to entirely non-temperate thermal conditions. Current driving stress and velocity are very low, and the glacier has almost certainly fallen out of the surge cycle. Within 60 years, there has therefore been a wholesale transformation in the geometry, thermal structure and dynamics of Scott Turnerbreen.
\end{abstract}

\section{INTRODUCTION}

The response of ice masses to climate warming is commonly quantified in terms of "static sensitivity", i.e. a water-equivalent (w.e.) mass-balance change for a given atmosphericwarming increment. However, this formulation neglects the dynamic feedback between glacier geometry and flow. Understanding the impact of mass-balance change on patterns of glacier behaviour is of considerable importance, given that mass-balance loss from mountain glaciers over the next 50 to 100 years is expected to be a significant proportion of present volume (Warrick and others, 1996). Furthermore, an understanding of dynamic feedback is key to recognising the non-equilibrium, spatially and temporally variable glacier properties that influence the development of glaciated landscapes. This paper documents 20th century changes in geometry and thermal regime at an Arctic glacier: Scott Turnerbreen $\left(3.3 \mathrm{~km}^{2}\right)$, located at $78^{\circ} \mathrm{N}$ in central Spitsbergen, Svalbard (Fig. la). Against the background that this glacier surged around 1930 (Hagen and others, 1993), the dynamic implications of the changes are discussed.

\section{METHODS}

\section{Surface topography}

The surface topography of Scott Turnerbreen was determined by field surveying during May 1993. The locations of 162 points were described by $x, y, z$ coordinates referred to a locally defined scheme. The instruments used were a Wild T2 universal theodolite and DI3000 timed-pulse electronic distance-measuring instrument (EDM). At each point, the snowpack was probed to determine the depth to the ice surface. In order to obtain absolute elevations, reference heights

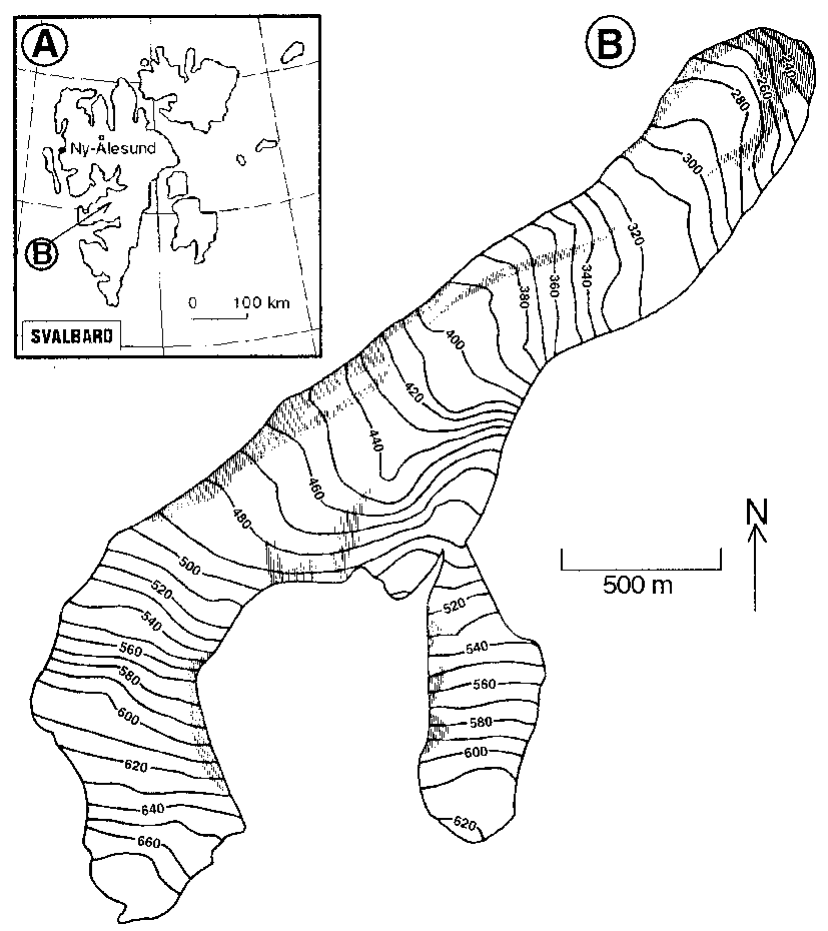

Fig. 1. (a) Scott Turnerbreen in Svalbard. (b) 1993 surface topography of Scott Turnerbreen: contours in $m$ a.s.l., shading denotes debris-covered areas. 
and a base line (digitized to an accuracy of $\pm 5 \mathrm{~m}$ at the scale of the map) were taken from the Norsk Polarinstitutt (NPRI) 1:100 000 topographic map sheet E9.

Distance data were corrected for prevailing atmospheric conditions, using lapse-rate-adjusted data from the Norwegian Meteorological Institute station at Svalbard Airport. The accuracy of the surveyed locations was determined by combining the standard deviations of distance and angle measurements. Repeat measurements were taken at the start and end of each survey round to a reference marker, and the error therefrom assigned to the measurements taken during that round. The mean error in $x$ and $y$ coordinates is $\pm 0.172 \mathrm{~m}$, with $91 \%$ of all errors being less than $\pm 0.5 \mathrm{~m}$. The mean error in $z$ coordinates is $\pm 0.636 \mathrm{~m}$, with $90 \%$ less than $\pm 1.5 \mathrm{~m}$. In addition, there is an error arising from the determination of the absolute elevations of the survey stations, calculated in the same way, amounting to $\pm 1.131 \mathrm{~m}$.

The surface topographic map of the glacier (Fig. 1b) was constructed using UNIMAP (UNIRAS) software, which takes irregularly spaced data and approximates them to a regular grid, using bi-linear interpolation. A $50 \times 50 \mathrm{~m}$ grid was generated and contoured at $10 \mathrm{~m}$ intervals. The glacier margin was defined by digitizing NPRI 1:15000 scale vertical aerial photographs from 1990.

\section{Bed topography and ice thickness}

The depth of the glacier was determined by continuous radio-echo profiling, with a range-gated, synthetic-pulse system (Hamran, 1989). Broad-band, end-fed dipole antennae, operating with a $50 \mathrm{MHz}$ bandwidth at a centre frequency of $65 \mathrm{MHz}$, were employed. Towed on a sledge by a snowmobile, the sampling rate is controlled by a distance wheel, giving equidistant spatial sampling at an interval of $4.3 \mathrm{~m}$. A signal is transmitted and the back-scattered signal received for 201 frequencies over the $50 \mathrm{MHz}$ bandwidth, giving a sampling interval of approximately $250 \mathrm{kHz}$. Data are collected in the frequency domain and an inverse Fourier transform is used to obtain the time function in physical space (Hamran and Aarholt, 1993). The resolution of the system in ice is $1.7 \mathrm{~m}$.

A $2181 \mathrm{~m}$ longitudinal section of the upper main glacier was completed at the 40-90 MHz frequency. The full longitudinal section of the glacier (length $4483 \mathrm{~m}$ ) was completed with data collected at the $320-370 \mathrm{MHz}$ frequency (see following section). The dielectric constant of ice was assumed to be 3.18 , giving a phase velocity of $168 \mathrm{~m} \mathrm{~s}^{-1}$ (Paterson, 1994). As the snowpack was thin (maximum depth $2.0 \mathrm{~m}$ ) and dry, a correction for the increased phase velocity in snow was unnecessary.

\section{Thermal regime}

The scattering of radar signals from water inclusions in temperate ice increases with the sounding frequency (Watts and England, 1976). Sounding at multiple frequencies therefore enables the mapping of both basal topography and thermal structure. Both Ødegård and others (1992) and Björnsson and others (1996) have used a synthetic-pulse radar, similar to that described here, operating at 5-20 and $320-370 \mathrm{MHz}$ frequencies to map, respectively, the bed topography and thermal structure of glaciers in Svalbard.

In order to assess the thermal regime of Scott Turnerbreen, the radar system described above was again deployed, but with six-element Yagi antennae, operating with a

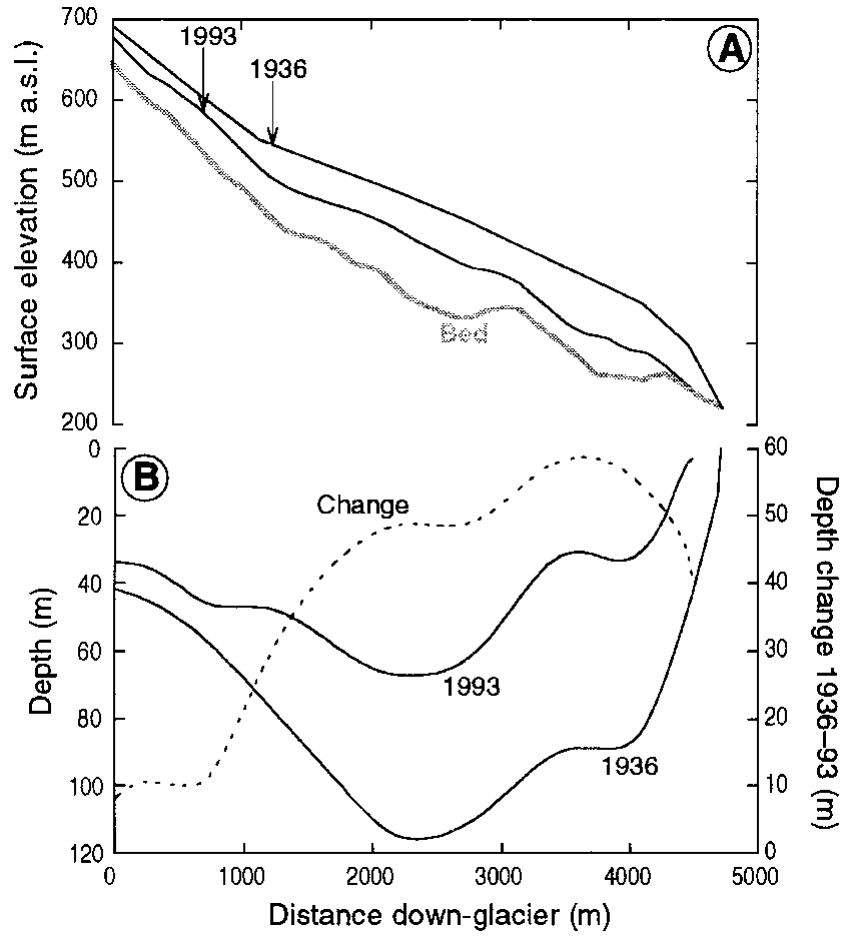

Fig. 2. (a) Centre-line surface profiles of Scott Turnerbreen in
1936 and 1993. (b) Centre-line ice depths in 1936 and 1993,
and centreline depth change 1936-93.

$50 \mathrm{MHz}$ bandwidth at a centre frequency of $345 \mathrm{MHz}$. Since the bandwidth is the same at the lower frequency, the sampling interval and resolution are unchanged. Some $2100 \mathrm{~m}$ of the main glacier was covered at low and high frequencies, enabling the returns from each to be compared. Ice temperature was also measured directly in two boreholes hotwater drilled through the glacier on its centre-line, at surface elevations of 305 (42 $\mathrm{m}$ depth) and $595 \mathrm{~m}$ a.s.l. (54 m depth). Each was instrumented with a cable, having thermistors (precision $\pm 0.2^{\circ} \mathrm{C}$ ) at $12.5 \mathrm{~m}$ intervals, with the lowermost thermistor at the base of the borehole. Final temperature readings were obtained 50-71 days after installation.

\section{RESULTS}

\section{Geometry and mass-balance change}

The 1993 glacier map was compared with that from NPRI map sheet E9 (1:100000), which is based on photogrammetric compilation from oblique aerial photographs taken in 1936 (Fig. 2). The accuracy of elevations on this map was never quantified, but is likely to be highly variable: the average uncertainty may be of the order of 25-50 m, although current remapping (from 1990 vertical aerial photos) indicates that it can be very much less (personal communication from H. Aas and B. Lytskjold, 1998). The results presented here are strongly believed to be robust, because of the high degree of consistency between both maps, the trend they indicate, and NPRI aerial photos acquired between 1936 and 1990. Nevertheless, no attempt has been made to quantify the total change in area of the glacier, as there is uncertainty in the exact locations of parts of the margins which cannot be satisfactorily resolved from the NPRI map. However, it is clear that substantial retreat and thinning of the glacier has occurred during the interval 1936-93. On the line of the longitudinal section, the glacier terminus has retreated approxi- 

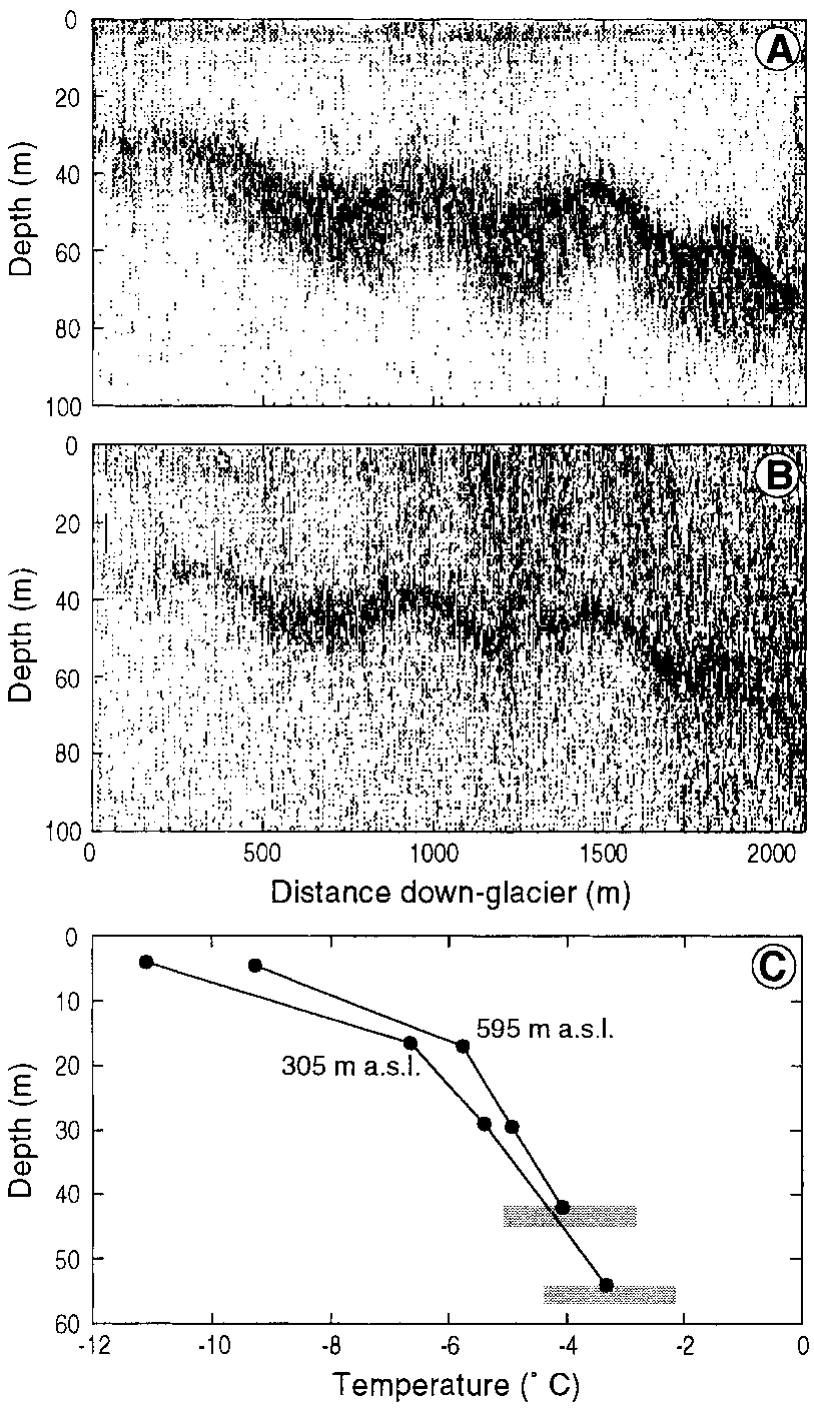

Fig. 3. (a) Centre-line synthetic-pulse radar return from upper Scott Turnerbreen, $65 \mathrm{MHz}$ centre frequency. (b) Synthetic-pulse radar return from the same section, $345 \mathrm{MHz}$ centre frequency. (c) Borehole temperature measurements.

mately $140 \mathrm{~m}$. Comparison of the 1993 longitudinal section with the same section in 1936, enables an estimate of the long-term net mass balance of the glacier to be obtained. Figure $2 \mathrm{a}$ shows the two sections together, in relation to the glacier bed, and indicates that thinning of the glacier has occurred at all elevations up to about $700 \mathrm{~m}$ a.s.l., but particularly below about $550 \mathrm{~m}$ a.s.l. The reduction in ice thickness indicated by the two sections (Fig. $2 \mathrm{~b}$ ) varies from $7 \mathrm{~m}$ to as much as $59 \mathrm{~m}$, with a mean of $36 \mathrm{~m}$ (well in excess of the 1993 survey uncertainty): this corresponds to a net mass balance over the whole period of $-0.58 \mathrm{~m} \mathrm{a}^{-1}$ w.e.

\section{Bulk thermal regime}

Figure $3 \mathrm{a}$ and $\mathrm{b}$ shows radar longitudinal sections of the upper main glacier at low $(40-90 \mathrm{MHz})$ and high $(320-$ $370 \mathrm{MHz}$ ) frequencies. It is clear that at both frequencies the same reflection is received at all points on the section. There is therefore no frequency-dependent limitation on radar penetration of the ice, which is interpreted to indicate the absence of temperate ice, i.e. the glacier is below the pressure-melting temperature throughout. Borehole depths confirm the interpretation of a reflection from the bed at both frequencies. Furthermore, the receipt of a high-fre- quency basal reflection near the deepest part of the glacier shows that temperate ice is unlikely to be present in the rest of the glacier where the ice is thinner. The brief loss of the high-frequency reflection at the lowermost part of the section probably stems from scattering from the valley sides.

\section{Borehole temperatures}

The evidence from high-frequency radar for a uniformly nontemperate thermal regime is supported by the borehole temperature measurements (Fig. 3c). These were stable throughout the monitoring period, indicating that the thermistors had reached thermal equilibrium with the glacier ice. At the top of each temperature profile is a low-gradient section representing winter conductive cooling (Hooke and others, 1983), which is attenuated at a depth of $16-17 \mathrm{~m}$. The temperature gradient in this part of the lower borehole is $+0.280^{\circ} \mathrm{C} \mathrm{m}^{-1}$, and in the upper borehole $+0.356^{\circ} \mathrm{C} \mathrm{m}^{-1}$, corresponding to heat fluxes of 0.588 and $0.748 \mathrm{~W} \mathrm{~m}^{-2}$, respectively.

The basal temperature in the lower borehole (depth $42 \mathrm{~m}$ ) was $-4.1^{\circ} \mathrm{C}$, and in the upper borehole (depth $54 \mathrm{~m}$ ) was $-3.3^{\circ} \mathrm{C}$. It is possible to calculate the depth of ice which would be required to bring the glacier bed to the pressuremelting temperature, from the temperature gradient in the boreholes, and the rate of depression of the melting point by pressure, $-0.00065^{\circ} \mathrm{C} \mathrm{m}^{-1}$ of ice (Raymond, 1980). Nearbasal temperature gradients of +0.068 and $+0.083^{\circ} \mathrm{C} \mathrm{m}^{-1}$ were obtained for the lower and upper boreholes respectively, corresponding to heat fluxes of 0.143 and $0.174 \mathrm{~W} \mathrm{~m}^{-2}$. The depth at which the pressure-melting temperature is reached is determined by deriving linear equations for the pressure-melting and borehole temperature gradients and solving them simultaneously. The depth of ice required for pressure-melting is thus calculated as $101 \mathrm{~m}$ for the lower borehole and $95 \mathrm{~m}$ for the upper borehole. It is therefore unlikely that ice reaches the pressure-melting temperature at the deepest part of the glacier $(76 \mathrm{~m})$.

\section{DISGUSSION}

\section{Mass-balance change}

The estimated 1936-93 net mass balance of $-0.58 \mathrm{~m} \mathrm{a}^{-1}$ w.e. can be compared with mass-balance records from other glaciers in Svalbard (Table 1). The longest records are available from Austre Brøggerbreen and Midre Lovénbreen. Over the period 1967-95, the net mass balances at these glaciers were -0.43 and $-0.36 \mathrm{~m} \mathrm{a}^{-1}$ w.e., respectively (Hagen, 1996). However, Lefauconnier and Hagen (1990) found a good multiple correlation $(R=0.90)$ between the net mass balance of Austre Brøggerbreen, summer and autumn positive degree-days, and winter precipitation. This allowed the mass-balance record of that glacier to be estimated, on the basis of meteorological records, as far back as 1912. The net mass balance over the interval 1921-88 increased from -0.63 to $-0.35 \mathrm{~m} \mathrm{a}^{-1}$ w.e., prior to which estimated mass-balance conditions were close to equilibrium. Negative massbalance conditions in Svalbard this century are generally linked to the termination of the Little Ice Age (LIA) over the northeast Atlantic region (Grove, 1988): meteorological records from western Svalbard show an abrupt rise in mean annual air temperature of up to $5^{\circ} \mathrm{C}$ after about 1920 (Hanssen-Bauer and others, 1990).

It therefore appears that long-term mass-balance condi- 
Table 1. 20th century net mass-balance data from Svalbard glaciers (Lefauconnier and Hagen, 1990; Lefauconnier and others, 1994; Hagen, 1996; this study)

\begin{tabular}{|c|c|c|c|c|c|}
\hline \multirow[t]{3}{*}{ Glacier } & \multicolumn{2}{|c|}{ Location } & \multirow{3}{*}{$\begin{array}{l}\text { Area } \\
\mathrm{km}^{2}\end{array}$} & \multirow[t]{3}{*}{ Period } & \multirow{2}{*}{$\begin{array}{c}\text { Net mass } \\
\text { balance }\end{array}$} \\
\hline & Latitude & Longitude & & & \\
\hline & & & & & $\mathrm{m} \mathrm{a}^{-1}$ w.e. \\
\hline Vøringbreen & $78^{\circ} 03^{\prime} \mathrm{N}$ & $13^{\circ} 58^{\prime} \mathrm{E}^{*}$ & 2.1 & $1974-91$ & -0.64 \\
\hline Scott Turnerbreen & $78^{\circ} 06^{\prime} \mathrm{N}$ & $15^{\circ} 57^{\prime} \mathrm{E}^{*}$ & 3.3 & 1936-93 & -0.58 \\
\hline Longyearbreen & $78^{\circ} 11^{\prime} \mathrm{N}$ & $15^{\circ} 30^{\prime} \mathrm{E}^{*}$ & 4.0 & 1977-82 & -0.55 \\
\hline Daudbreen & $78^{\circ} 19^{\prime} \mathrm{N}$ & $16^{\circ} 07^{\prime} \mathrm{E}^{*}$ & 4.5 & $1976-83$ & -0.36 \\
\hline Bogerbreen & $78^{\circ} 55^{\prime} \mathrm{N}$ & $11^{\circ} 44^{\prime} \mathrm{E}^{*}$ & 5.2 & $1975-86$ & -0.43 \\
\hline Bertilbreen & $78^{\circ} 41^{\prime} \mathrm{N}$ & $16^{\circ} 16^{\prime} \mathrm{E}^{*}$ & 5.4 & $1975-85$ & -0.67 \\
\hline Midre Lovénbreen & $78^{\circ} 53^{\prime} \mathrm{N}$ & $12^{\circ} 04^{\prime} \mathrm{E}$ & 6.0 & 1968-95 & -0.36 \\
\hline Austre Brøggerbreen & $78^{\circ} 54^{\prime} \mathrm{N}$ & $11^{\circ} 50^{\prime} \mathrm{E}$ & 11.8 & $\begin{array}{l}1912-88 \\
1967-95\end{array}$ & $\begin{array}{l}-0.45 \\
-0.43\end{array}$ \\
\hline Grønfjordbreen & $77^{\circ} 54 / \mathrm{N}$ & $14^{\circ} 15^{\prime} \mathrm{E}$ & 38.3 & 1988-91 & -0.40 \\
\hline Finsterwalderbreen & $77^{\circ} 29^{\prime} \mathrm{N}$ & $15^{\circ} 15^{\prime} \mathrm{E}$ & 44.5 & $1950-68$ & -0.51 \\
\hline Fridtjovbreen & $77^{\circ} 50^{\prime} \mathrm{N}$ & $14^{\circ} 26^{\prime} \mathrm{E}$ & 48.7 & $1987-91$ & -0.32 \\
\hline Hansbreen & $77^{\circ} 04^{\prime} \mathrm{N}$ & $15^{\circ} 38^{\prime} \mathrm{E}$ & 57.0 & 1989-95 & -0.62 \\
\hline Kongsvegen & $78^{\circ} 48^{\prime} \mathrm{N}$ & $12^{\circ} 59^{\prime} \mathrm{E}$ & 105.0 & $\begin{array}{c}1962-90 \\
1987-95\end{array}$ & $\begin{array}{l}-0.10 \\
+0.06\end{array}$ \\
\hline
\end{tabular}

* Located in central Spitsbergen.

tions at Scott Turnerbreen are consistent with those at Austre Brøggerbreen, although possibly more negative. Is this a reflection of regional trends? Table 1 lists net mass-balance data from glaciers of a range of sizes across Svalbard. Some Soviet measurements reported by Hagen (1996) are instructive. Over all or part of the period 1974-91, mean net massbalances at five other glaciers $\left(2.1-5.4 \mathrm{~km}^{2}\right)$ in central Spitsbergen ranged from -0.36 to $-0.67 \mathrm{~m} \mathrm{a}^{-1}$ w.e. There appears to be a northwest--southeast trend towards less negative mass balance, broadly in accordance with the precipitation pattern in this part of the archipelago (Hagen and others, 1993). The net mass balance estimated for Scott Turnerbreen therefore falls within the range of observed balances in this part of Svalbard. This provides further independent evidence that the results obtained by comparing the NPRI 1936 map and the 1993 map are unlikely to be significantly in error. The mean winter balances, $0.52 \mathrm{~m}$ w.e. at Bogerbreen $(8 \mathrm{~km}$ northwest of Scott Turnerbreen) and $0.48 \mathrm{mw}$.e. at Longyearbreen (13 km northwest of Scott Turnerbreen), are close to the $0.54 \mathrm{~m}$ w.e. measured at Scott Turnerbreen in 1993.

\section{Thermal regime change}

Given the observed temperature gradients, but the 1936 ice thickness distribution, the melting point would have been reached through pressure over about $2 \mathrm{~km}$ of the length of the glacier bed. However, this is probably a minimum estimate of the former extent of temperate ice. In an Arctic region like Svalbard, temperate ice is generated not only by pressure-melting, but also in "wet snow" areas, where there is partial melting of the snowpack. This arises partly from insulation from winter conductive cooling by a perennial snow cover, but mainly from the release of latent heat of fusion by the refreezing of meltwater percolating through the snowpack (Hooke and others, 1983). This thermal regime therefore indicates areas where there is net accumulation, despite the occurrence of melting. Hence, the boreholes on Scott Turnerbreen are unlikely to be located in the glacier's accumulation area.
However, prior to 1936, the mass balance of Scott Turnerbreen must have been, at least, less negative than from 193693. One might therefore speculate that the accumulation area would then have been greater in extent and the equilibrium line lower in altitude. It would then follow that temperate ice would have formed throughout the glacier thickness beneath "wet snow" areas, in addition to forming near the bed by strain heating. It is therefore suggested that Scott Turnerbreen is likely to have been polythermal, with a largely temperate accumulation area (due to insulation from a perennial snow cover, latent heat retention in partially melted snow, and pressure-melting beneath thicker ice) and a largely non-temperate ablation area (due to reduced insulation from a seasonal snow cover, kinetic heat loss with runoff from ice surfaces, and limited pressure-melting beneath thinner ice near the terminus and margins).

\section{CONGLUSIONS}

There has been a clear association of significant mass balance, geometry and thermal regime change at Scott Turnerbeen over about 60 years. These changes have been forced by a well-documented, step-like climate change earlier this century. Having surged around 1930, Scott Turnerbreen would have entered the warmer, post-LIA period with a depleted accumulation area and enlarged ablation area, making it particularly vulnerable to reduced mass-balance conditions. In order to have surged in the years preceding 1936, Scott Turnerbreen must have been capable of sustaining rapid flow by basal motion, requiring melting temperatures over a significant part of the glacier bed. However, given the 1993 thermal regime, such motion is now clearly impossible, while the rate of ice deformation is limited by the sub-freezing temperatures, as well as by the reduced ice thickness. Indeed, current rates of glacier flow are very low: basal shear stress is 17-68 (mean 35) $\mathrm{kPa}$, and surface velocity is $0.01-0.48$ (mean 0.09) $\mathrm{m} \mathrm{a}^{-1}$ (Hodgkins, 1994).

Climate and mass-balance change at Scott Turnerbreen have therefore led to significant change in the thermal character of the glacier, and ultimately in its dynamics. No buildup of ice has occurred since at least 1936, and the glacier is entirely frozen to its bed. Hence, there is no prospect of renewed surge activity. This reflects the failure of the glacier to accumulate mass and therefore build up a surge-reservoir area, which could generate the critical geometry required to trigger the active phase. There is no reason to believe that any change in the mechanism of surge regulation has occurred; thus, the results presented here do not support thermal regulation of glacier surging. Scott Turnerbreen therefore exemplifies comprehensive glacier change, forced by documented Holocene climate change (the termination of the LIA in Svalbard) with an initial non-steady-state glacial boundary condition (the post-surge glacier geometry).

\section{ACKNOWLEDGEMENTS}

The support of J. A. Dowdeswell and United Kingdom Natural Environment Research Council studentship GT4/ 91/AAPS/11 is gratefully acknowledged. I. Goodfellow and N. F. Glasser assisted with the topographic survey. The comments of M. Funk, an anonymous referee and the editor, R. G. A. Hindmarsh, helped improve the text. 


\section{REFERENCES}

Björnsson, H. and 6 others. 1996. The thermal regime of sub-polar glaciers mapped by multi-frequency radio-echo sounding. F. Glaciol., 42(140), 23-32.

Grove, J. M. 1988. The Little Ice Age. London, Methuen \& Co. Ltd.

Hagen, J. O. 1996. Svalbard. In Jania, J. and J. O. Hagen, eds. Mass balance of Arctic glaciers. Sosnowiec/Oslo, International Arctic Science Committee. Working Group on Arctic Glaciology, 30-38. (IASC Report 5.)

Hagen, J. O., O. Liestøl, E. Roland and T. Jørgensen. 1993. Glacier atlas of Svalbard and Jan Mayen. Nor. Polarinst. Medd. 129.

Hamran, S.-E. 1989. Geophysical electromagnetic backscatter tomography: experimental results from glacier study. (D.Sc. thesis, University of Tromsø.)

Hamran, S.-E. and E. Aarholt. 1993. Glacier study using wavenumber domain synthetic aperture radar. Radio Sci., 28(4), 559-570.

Hanssen-Bauer, I., M. K. Solås and E. L. Steffensen. 1990. The climate of Spitsbergen. Oslo, Norsk Meteorologisk Institutt. (Rapport 39/90.)

Hodgkins, R. 1994. The seasonal evolution of meltwater discharge, quality and routing at a High-Arctic glacier. (Ph.D. thesis, University of Cambridge.)

Hooke, R. LeB., J. E. Gould and J. Brzozowski. 1983. Near-surface tempera- tures near and below the equilibrium line on polar and subpolar glaciers. Z. Gletscherkd. Glazialgeol., 19(1), 1-25.

Lefauconnier, B. and J. O. Hagen. 1990. Glaciers and climate in Svalbard: statistical analysis and reconstruction of the Brøggerbreen mass balance for the last 77 years. Ann. Glaciol., 14, 148-152.

Lefauconnier, B., J. O. Hagen, J. F. Pinglot and M. Pourchet. 1994. Mass-balance estimates on the glacier complex Kongsvegen and Sveabreen, Spitsbergen, Svalbard, using radioactive layers. F. Glaciol., 40(135), 368-376.

Ødegård, R. S., S.-E. Hamran, P. H. Bø, B. Etzelmüller, G. Vatne and J. L. Sollid. 1992. Thermal regime of a valley glacier, Erikbreen, northern Spitsbergen. Polar Res., 11 (2), 69-79.

Paterson, W. S. B. 1994. The physics of glaciers. Third edition. Oxford, etc., Elsevier. Raymond, C. F. 1980. Temperate valley glaciers. In Colbeck, S. C., ed. Dynamics of snow and ice masses. New York, Academic Press, 79-139.

Warrick, R. A., C. le Provost, M. F. Meier, J. Oerlemans and P. L. Woodworth. 1996. Changes in sea level. In Houghton, J.T., L. G. M. Filho, B. A. Callander, N. Harris, A. Kattenberg and K. Maskell, eds. Climate change 1995: the science of climate change. Cambridge, etc., Cambridge University Press, 359-405.

Watts, R. D. and A.W. England. 1976. Radio-echo sounding of temperate glaciers: ice properties and sounder design criteria. f. Glaciol., 17(75), 39-48. 